\title{
Vulnerability of Elderly Women: Victim of Gender Discrimination
}

\author{
Subir Kumar Roy \\ Department of Law, Bankura University \\ Bankura Block-II, P.O. Purandarpur, Bankura, West Bengal 722155, India \\ Tel.: +91-9733-215777E-mail:_dr.roysubir@gmail.com \\ Submitted: Dec 1, 2016; Reviewed: Mar 20, 2017; Accepted: Mar 24, 2017
}

\begin{abstract}
The life cycle of human being completes with the process of aging but we fail to realize this simple arithmetic of life and often consider our elders as a burden for us. They are compelled to compromise with their dignity and integrity and forced to live at the mercy of their own nearest and dearest. When we talk about elderly women their position is more appalling than their male counterpart due to this male chauvinism which tries to regulate every affair of the life of the people. Under the alibi of protection and security of women they are subjected to the violent gender discrimination and compelled to live and lead their life at the fingertips of a male. The women in especially in third world countries are considered as a tool of procreation of child and all her activities and qualities of life are relegated with the household course. Across the globe the male tendency is to regulate Women's ownership and control of property, resources created by her own labor, education and information and even her reproductive abilities and sexualities with an intention to jeopardize and throttled down the rights of the women. Women bear this status till her last breath and hence, it is axiomatic that how vulnerable their position is.
\end{abstract}

Keywords: Aging; Elderly Woman; Gender Discrimination; Human Rights

DOI: 10.20956/halrev.v3i1.560

\section{INTRODUCTION}

Aging is a natural process of the life cycle of human being but the elderly people are often subjected to abuse, insult, physical and mental torture and astonishingly in most of the time the ill treatment is inflicted against them by their own family members or relatives. The inhuman treatment of the society affects the dignity and integrity of the aging people especially the elderly women. In third world countries, most of the elderly women struggle hard for the existence of their physical entity, wait for the mercy and philanthropic pursuits from their family members in getting the meals of two times of a day and the words like mental recreation, comfort, hospitality, health facilities, equality, expectation of social solidarity etc. are the word of illusion to them and carry no meaning.

Aging refers to the transition of population structure which happens due to the 
decline in fertility and decreases in the share of the young and also due to the advancement of health system and the invention of life saving drugs which increases the chances of survival and life expectancy. The family planning schemes are also responsible for the changes in population structure and the growth of aging population. So, aging becomes omnipresent and it is the need of the hour to inform justice to them by formulating the necessary policies, legal instruments etc. so that the old people should not be compelled to compromise with their dignity and they should be actively engaged with the socio-economic and political structure of the society.

Gender discrimination arises from male chauvinism as Patriarchy creates hindrance in all facets of life of women and regulates Women's ownership and control of property, resources created by her own labor, education, information even women's reproductive abilities and sexualities and thus crippled down the rights of the women. It is axiomatic from the above proposition that elderly women too cannot remain detached from the gender discrimination though the nature of discrimination depends upon the socio-economic and political situation of a society and also on the basis of household composition.

In the third world countries like India it has been found the women get widowed more than men, illiterate and economically crippled which make their life miserable during old age. The elderly women are being deprived of sharing the material resources of the society and policies are seldom formulate to ensure all round development of women and improving opportunities in their life. In the backdrop of above, the objective of this article is to discuss about the aging population especially about aging gender and its impact on society, outlook of the world polity towards the conditions of the elderly women and the legal measures therein.

\section{ANALYSIS AND DISCUSSION Gender Discrimination and Aging: A Re- sultant of Rift between Culture and Power}

Though aging is nothing but a stage of the lifecycle like babe-in-arms, toddler, infant, child, adolescent, adult etc. but we seldom see our future in the faces of elderly people. The fundamental rights of elderly people are being ravished and crushed regularly either by their own family members or by the society and they are deprived from enjoying quality life. However, the violation of the right of the aging people is not homogeneous across the globe as it varies on the basis of socio-economic and cultural differences in the countries. But so far, the conditions of elderly women are considered are most vulnerable and worst than the men across the globe, though, severity of the problem may be different in different parts of the world.

The freedom of the elderly women is under critical and pervasive threats and this situation is deeply connected with the gender discrimination. Feminists consider women suffer the oppression for being women, other than men (Bernard, Chambers and Granville) ${ }^{1}$. The profounder of liberal feminist consider the sufferings of women

\footnotetext{
Miriam Bernard, Judith Phillips, Linda Machin and Val Harding Davies. (2000). Women Ageing: Changing Identities, Challenging Myths. London: Routledge, p. 10.
} 
are due to the deprivation of them form the different amenities of life, civil rights, education etc. They believe that not by change in the structure of society rather by acknowledging the rights of the women and through incorporating necessary legislations and reformative policies, the conditions of the women can be ameliorated. Liberal feminists believe state can be used as a potent weapon to act as the harbinger of justice by ensuring the notion of equality and protective discrimination in favor of women through political and legal reform. The proponents of liberal feminism highlighted the issues like reproductive and abortion rights, right to vote, education, equal pay for equal work, proper health services etc.

Radical feminists believe the cause of the oppression of women is rooted with the inherently oppressive and dominating patriarchal society. The power structure of the society always inclines towards the male chauvinism and unless and until this structure of the society is hammered the women cannot be able to overcome their sufferings. Some radical feminists advocate for reconstruction of the society in order to uproot the traditional values of the male dominated society which is responsible for (Bernard, Chambers and Granville) ${ }^{2}$ the inhuman wrong for the women. Radical feminists consider that one of the main roots of the inhuman condition of women is the control of male over her body through sexuality, reproduction. Motherhood and rape and for women emancipation it is needed for the women to control her body herself.
On the other hand, the Marxists linked the gender oppression with class struggle. They claim the unequal status of women put them into disadvantageous position in both the workplace and domestic spheres of life. Marxists claim that oppression of individuals is unleashed from dominant power structure, regulated by the capitalists and inequality in social. Political and mainly economic front lead to the exploitation of individuals including women. Economic inequality crippled down the freedom of women, causes them to depend on their male counterpart for their existence and also create some kind of unhealthy relationship.

Rosa Luxemburg recognized that women derive their class position, with concomitant privileges and restrictions from their associations with men. ${ }^{3}$ According to her, notion due to this reason women never have been able to fight united against the male chauvinism. Marxist claimed uneven power sharing and capitalistic productivity is responsible for all kind of oppression of people including gender discrimination. Luxemburg has gone to extent and said the difference in between bourgeois women from her domestic servant is that the later is paid while the former is kept. Luxemburg termed the bourgeois women as "parasite of parasite" while proletarian women as "slave of a slave" but the bourgeois women fail to realize this indignity of life. $^{4}$ So capitalism coupled with the patriarchy and unconsciousness about class struggle is responsible for women oppression.

Catherine A. MacKinnon. (1982). "Feminism, Marxism, Method, and the State: An Agenda for Theory." Signs: Journal of Women in Culture and Society, 7(3), 515-544.

$4 \quad$ Ibid 
Apart from the above approaches of feminism the concept like post-modern feminism, cultural feminism, eco-feminism etc. are there but the aim of this present paper is neither to discuss about the political theories attached with feminism nor the theme of the paper allows doing so. Some approaches of feminism has been discussed here as a tips of iceberg to through light on some root causes of the gender problems, to highlight patriarchal aggression and the sufferings of gender. However, the different approaches on feminism reflects the rising consciousness of the feminists for their emancipation from the oppression of the patriarchal system which helped in development of the feminist jurisprudence.

No doubt, the various welfare legislations as well as the strict criminal laws have been incorporated in the legal system of the countries in different phases for the safety, protection and wellbeing of the women but still the feminists never consider that they are treated as a full person in the eye of law. In many part of the globe including India marital rape has not been recognized as a criminal offence, which clarifies that still women have no control over their own body and reproductive system and till the date in most of the countries, women possess very weak property rights and political rights and even where they get the equal rights they fail to appropriate them properly due to their disadvantageous position and poor social, economic and political conditions.

Both 'sex' and 'gender' are much contested term and somehow related with the sufferings of the women. The theorists like Stoller, Archer, Harraway, Hood-Williams,
Scott believe that sex is fixed by nature and often produces gender whereas Butler, Gatens, Antony, Hird claim sex is not determined by biology but is produced socially and culturally. ${ }^{5}$ The theorists like Staller etc. believe that sex is a biological process and accordingly 'maleness', 'femaleness' etc. depends upon the genital organs whereas gender is the socially and culturally construed theme whereby the society assigned different norms, duties and roles on male and female and needless to mention the patriarchal society never allowed the female to become full person in the eye of law in the sense that women are not allowed to enjoy all sorts of rights available to their male counterpart. Beauvoir said one is not born a woman, but rather becomes one. ${ }^{6}$

On the other hand, the exponents like Geddes, Thompson etc. are there who believe the gender identity grows from biological nature which consider men are inherently 'catabolic' and women as 'anabolic'. While male sex is bestowed with the adjectives like assertiveness, independence, confidence, activeness, aggressiveness, enterprise, impersonality and recklessness, the female sex are with the terms like passivity, submissiveness, emotion, caring, gentleness, warmth, sensitivity, receptiveness, expressiveness and biological economy.

The above adjectives are purposefully used in division of labor and in deciding the capabilities of male and female. It is argued on behalf of them that due to the physiological and psychological structure the women

\footnotetext{
Babatunde, Ekundayo B, and Babatunde E. Durowaiye. (2015). "The Conception of 'Sex' and 'Gender' as Background to Inequities Faced by Women.” The Journal of Pan African Studies, 7(8): 64-79.

6 Ibid
} 
are suited better in nursing of child and in doing the household chores while male are suited better to work for earning money to meet the livelihood of the family members. Due to the above reason a considerable number of feminists believe that sex is not determined on biological ground rather very much depends on social and cultural fabric of the society.

So, male chauvinism denied the basic and most important right of the women i.e. to live with dignity and it controls the fertility, mobility, productivity and sexuality of women. Women bear the lion share of responsibility in the upbringing and welfare of the family but her contribution is not properly valued by the male dominated society. Despite, of women's tireless effort and contribution for the well-being of the family, the family as well as the society invest minimum to fulfill the prime needs of the females and as a matter of fact they are being deprived from having the health facilities, education, nutritious diet etc. in workplace too, women never get the proper environment to lead dignified life. Due to weak laws and biased policies often the women get least of salary in comparison to their male counterpart. even in dignified services the women are not engaged in decision making process due to the peculiar mind set-up of the patriarchal society where the always either neglect or doubts the ability and quality of women being.

Violence against women appears in many forms and ranges from physiological torture including sexual abuse to mental torture. Woman is bound to follow the norms of the patriarchal society even if it bleeds her soul or hurt her dignity; otherwise she will suffer the physical torture. The sufferings and indignation of the women starts from the time of her being in fetus stage and continue till before the death. Killing of female fetus becomes a general feature of the society, though in some part of the globe including India ban has been imposed on sex determination tests and laws have been framed related to abortion. Worldwide, violence against women is a major contributor to the mortality and morbidity of them. Women become the prime target of all sorts of conflicts whether the conflict is state sponsored or against the state.

Unleashing violence against the women is not always done with the object of satisfying or gratifying the lust but also with an intention to ruin the vigor and strength of a community because if the terror will be reigned on women and will be compelled to be confined within the four wall of her house, which will not allow her to have education or sharing views with other, her family will automatically be uneducated and backward. That is why miscreants, terrorists, fundamentalists' target the women at first by taking the opportunity of their vulnerable position in order to cripple down and jeopardize the development of the society. Rape, sexual abuse and harassment, outraging modesty, trafficking, honor killing, forced pregnancy during armed conflict, sexual slavery, forced sterilization, forced abortion etc. are the means applied to subjugate a woman including the patriarchal tactics of keeping her out from the developmental process so that women will remain women only not the human being. 
The General Assembly recognizes in the recital of the United Nations Declaration on the Elimination of Violence against Women, 1993 (A/RES/48/104) that violence against women is a manifestation of historically unequal power relations between men and women which enable men to dominate over women, subjected them to violence and to crippled down their advancement. The first report of the UN Special Rapporteur on Violence against Women states:

"The system of male domination has historical roots and its functions and manifestations change over time. The oppression of women is therefore a question of politics, requiring an anal$y$ sis of the institutions of state and society, the conditioning and socialization of individuals and the nature of economic and social exploitation".?

The rapporteur further observes in context of power relations that it is the man who controls the knowledge systems of the world whether it is science and modern technology or religion and its edicts and women are excluded from this knowledge system or their experiences are devalued and privatized. Men control the public world which becomes the institute of power and vindication of right and women are subjected to act within the domestic spheres. ${ }^{8}$

Actually, the family is the unit from where the discrimination starts against the female as it values the male not for having any qualities but simply for having the male sex and female are socialized to accept that they are inferior than male members and cannot act independently rather for all their

\footnotetext{
Report of Special Rapporteur on VAW 1995

Radhika Coomarswamy. (2005). "Human Security and Gender Violence." Economic and Political Weekly, 40, 44/45: 4729-4736.
}

acts they are required to depend on male members of their family.

Hence, our elderly women suffer both for being woman and also for being old. Though the sufferings are not homogeneous and vary on the ground of family and household status, socio-economic conditions, life style, culture and polity of countries, quality of social security and health systems, and sensitivity of the people of the country concern etc. but almost in all society aging women are deprived form having quality life.

The family division of labor and the process of engendering men and women of this patriarchal system attribute the different personalities and responsibilities on male and female and as per that mechanism it glorifies the mothering capacities of women and conditioned her life in such a way so that she cannot work independently and throughout the life she has to remain dependent on her male counterpart for all her aspirations and needs. So, the older women after passing of their husband become alone in latter life and for their livelihood they are compelled to depend on their family members or relatives as most of the women are made financially crippled due to its own system of division of labor and financially able widow are also forced to depend on family as the society keep them physically and mentally handicapped. These old women are considered as burden and as an 'outsider' in most of the family and in turn they often subjected to abuse and ill treatment etc.

The various study have shown that women live more than male members so naturally they bear greater risk of ailments 
and diseases in latter stage of life, which involve extra monetary burden but due to the weak financial position or due to indifferent attitude of the family members they don't get the proper health facilities and as a matter of fact their own life become burden to them. In most of the part of the globe our aging women are being deprived from the bare necessities of life and quality of life sounds utopian to them.

No doubt, the human rights of older people irrespective of gender approach are brutally infringed, but even than the trajectories of older women and their position in the society are bitterly affected by the gender role. As the women are from their very childhood are victim of the oppressive and discriminatory governing system of the society and being treated by the traditional culture and beliefs which are highly tilted towards male chauvinism and never allow them to take independent decision about their own course of life and from the very inception the very thought inscribed in their mind that they are inferior to male members as male and not the female are strong, knowledge oriented, powerful and entrusted with the qualities of decision making abilities, they are the natural choice to decide the fate of the female members of the family. This dependency grows with the age and as a matter of fact the society exploits them more and more by taking the opportunity of their miserable condition.

\section{Conditions of Elderly Women: Peeping}

\section{Through Real Stories}

Patricia Moore, an internationally acclaimed gerontologist and designer and author of the world-famous book 'Disguised: A
True Story' and 'The Business of Aging' has revealed the true status and position of our elders through her own life. Pat Moore was born in Buffalo, New York, USA in a family consisted of her two sisters, Parents and grandmother. After completing her undergraduate degree in Design from Rochester Institute of Technology she found in the period of 1974 the design and architecture industries of America were not keen to make design for the elder people rather they were interested more to get the customers below the age of 35 . Being impressed with the gracious life of her grandma it haunted her like anything that who would take care of the old people. In her interview to Janet Wilmoth, Director of the Syracuse University Aging Studies Institute, ${ }^{9}$ said that whenever she raised with little bit of timidity as she was alone female member in her office of 350 architects, designers and engineers about designing for aging groups she use to get the reply from the colleagues that they were not ready to do the same for 'those' people. ${ }^{10}$

The word 'those people' assailed the ears of Moore and she herself found 'that to be an elder was not a desirable goal and that to be older was enormously feared. ${ }^{11}$ Patricia Moore wanted to get the real experiences about the conditions of aging women and for that she thought not to rely on her imaginary power rather to reach on the stage of old and to see the conduct of the society towards aging group. With the help of designer Barbara Kelly she had taken the makeup of an elder

\footnotetext{
Center for Policy Research (CPR) at the Maxwell School of Syracuse University. "Quality of Life for All Ages, By Design, A conversation with Patricia Moore." Policy Brief. No. 46/2012.

10 Ibid

11 Ibid
} 
woman just like her grandmother and in that character she travelled to 116 cities in 14 states of America and 2 Canadian provinces for three years from May 1979 until October of 1982 and needless to mention that was the toughest and hardest task what she self- imposed on her to realize the misery of the elders. She found in the character of old woman that often she was treated with cruelty. She told to Janet that she was shortchanged by unscrupulous clerks and overchanged by caring cab drivers. She noticed the people often ignored her quiet requests and behaved with her rudely. On two occasions while she was in character of old woman, was mugged and in one incident she was mercilessly beaten by a gang of boys which injured her severely and snatched the capacity of her to become mother.

This unfortunate, barbaric and cruel episode signifies the ferocity of elder abuse. Patricia Moore keeping her life at risk exposed the pitiable and inhuman conditions of the aging people mainly women. The incident what happened with Eryetha Mayberry, 96 years old and a dementia patient at a nursing home in Oklahoma City is heart rendering and exposes the extreme and aggravated form of cruelty and granny battering. Doris Racher daughter of Eryetha Mayberry found that whatever the pretty small things she brought for her mother like nightie, lipstick, toothbrush etc. had been disappearing. Seeing this she installed a 'granny cams' in 2012 to catch the offender. Nearly after two months the family decided to go through the recordings to give a lesson to the thief but they became shuddered to see the contents. They found that a person 'stuffed latex gloves into Mrs. Mayberry's mouth while another taunted her, tapping her on the head, laughing. Hoisting her from her wheelchair, they flung her on a bed. One performed a few heavy- handed chest compressions. ${ }^{12}$ This incident clarifies the unsafe and inhuman condition of the aging people especially the old one.

On 14 $4^{\text {th }}$ March, 2015 a 71-year-old nun of a convent school was gang raped in a place named Ranaghat in West Bengal, India. The injury was so fatal that she had to undergo a surgery. This heinous incident exposes the unsafe position of the aging women. Perhaps, this is the right place and timing to recall the sorrowful episode of Shah Bano of India ${ }^{13}$ who exposed the inhuman and humiliating attitude of patriarchal society towards women through her own misfortune caused by none than other, her husband.

Her husband Mohammed Ahmad Khan who was a well-known advocate and belonging from the affluent section of the society had drove Shah Bano from their home almost after 43 years of their marriage life. At that time Shah Bano was of 60 years of age. Initially he agreed to give Rs. 200 monthly as maintenance to her while his income was stated as Rs. 60,000 per annum. He had continued it for nearly 2 years and thereafter dispensed himself from giving any kind of assistance for the livelihood of Shah Bano as well as for their children begotten through

\footnotetext{
12 Hoffman. (2013). "Watchful Eye in Nursing Homes." The New York Times. This article appears in print on 11/19/2013, on page D1 of the NewYork edition with the headline: Watchful Eye in Nursing Homes. Available online at: https://well.blogs.nytimes.com/2013/11/18/ watchful-eye-in-nursing-homes/? $\mathrm{r}=0$ [Accessed on 26th March, 2016].

13 Mohd. Ahmed Khan vs Shah Bano Begum And Ors. 1985 SCC (2) 556
} 
Shah Bano. Finding herself in hapless situation she compelled to file a petition for maintenance@ Rs.500 monthly u/s 125 of Cr.P.C in the Court of the Judicial Magistrate (First Class) Indore. In the meantime he had given irrevocable divorce (Talaq) to her in the year 1978 and thereafter had taken the plea before the court that as he had given divorce to her and before the divorce he gave her Rs.200 monthly as maintenance to her for 2 years and also had deposited Rs.3000 as 'Mahr' during the period of 'iddat', he should be absolved from all kind of liabilities.

The learned Magistrate ordered for a princely sum of Rs. 25 per month and that amount was enhanced to Rs. 179.20 per month by the high Court of Madhya Pradesh in response to a revision petition filed by Shah Bano. To subvert the decision of High Court her husband Mohammed Ahmad Khan filed appeal on the ground that as he fulfilled all the norms directed by his personal law, he should be relieved from following the order passed by the said High Court.

In this matter some Muslim religious organizations have also thrown themselves as party and Muslim Personal Law Board had also pleaded before the court that as per their personal law a Muslim male is only under the obligation to give maintenance during the period of 'iddat' and the due dower (deferred dower) after divorce to his wife. They also claimed that even thereafter that woman not been able to maintain herself then she may claim the maintenance from the relatives from the side of her parents. However, the Supreme Court in this case made it clear that the provisions related to maintenance in Cr.P.C. is secular law and applicable to all and has an overriding effect on all personal laws. The court has also clarified that dower or 'mahr' is for marriage and it cannot be equated as assistance against divorce and thus upheld the order of maintenance $\mathrm{u} / \mathrm{s} 125$ of Cr. P.C. granted in favour of Shah Bano.

The heartrending episode of Shah Bano Begum pointed out the attitude of the society towards the fair sex and also towards the aging women. After marriage a male and female both contributes and give labor to nurture their family and acquiring property but this patriarchal society never consider the woman as an equal partner of the marital property and house. Though now the attempt is being initiated within various legal systems to strengthen the position of women in this regard but still in major part of the globe the women are living the life of Shah Bano to drive from the matrimonial home at any point of time even after spending the conjugal relationship for more than forty years!

In this case, along with the husband of Shah Bano Begum the Muslim religious organizations like Muslim Personal law Board had lost the prudence to consider the age of the Shah Bano, which was 60 years at that point of time. Her poor economical as well as social position and they claimed that even after getting the dower, if she could not maintain her then she might claim assistance from her relatives from the side of her parents.

How irrational there thinking waswhen she had been refused by her husband with whom she spent 43 years of conjugal relationship refused to maintain her at her 60 years of her age. Is it not a day dream to 
imagine that her relatives will come ahead for her maintenance. This reflects the height of the hypocrisy of the male dominated society and also clarifies the pain and indescribable sufferings of aging women.

Fundamentalists had not allowed Shah Bano Begum to lead her august days of life peacefully. Government of India brought Muslim Women (Protection of Rights on Divorce) Act, 1986 to appease the fundamentalists and to override and nullify the judgment of Mohd. Ahmed Khan vs. Shah Bano Begum and Others 1985 SCC (2) 556. However, thanks to Indian Judiciary for its selfassigning role of 'harbinger of justice' and 'pro bono publico' stand by which right from Danial Latife ${ }^{14}$ to Khatoon Nisa (SCALE) ${ }^{15}$ and finally in Shamim Bano case (www.judis. nic.in $)^{16}$ the Supreme Court of India clarified that Muslim Woman can claim maintenance unless she gets remarriage either under sec. 125 of Cr. P.C. or under Muslim Women (Protection of Rights on Divorce) Act, 1986. If she is unable to maintain herself even after having the deferred dower and maintenance for the period of 'iddat' from the divorced husband. The supreme court observed in Khatoon Nisa case (SCALE): ${ }^{17}$

"When the marriage breaks up, a woman suffers from emotional fractures, fragmentation of sentiments, loss of economic and social security and, in certain cases, inadequate requisites for survival. A marriage is fundamentally

14 Danial Latifi and another v. Union of India.(2001) 7 SCC 740

15 Khatoon Nisa v. State of U.P. and Ors. 2002 (6) SCALE 165.

16 "Shamim Bano vs Asraf Khan." Criminal Appeal No. 820 of 2014 (Arising out of S.L.P. (Criminal) No. 4377 of 2012): Available online at: www.judis.nic.in. Accessed 26 ${ }^{\text {th }}$ March, 2016

17 Supra note 15 a unique bond between two parties. When it perishes like a mushroom, the dignity of the female fame gets corroded. It is the law's duty to recompense, and the primary obligation is that of the husband".

It is claimed that Shah Bano Begum was forced by the fundamentalists to refuse the Judgment of Supreme Court as it was a sin and against spirit of Muslim personal law. She had to live her end life almost of a destitute and ultimately died of brain hemorrhage. Her death is still asking the unanswered question how long the society will play with the dignity of women and compelled to live the life of misfortune.

\section{The Attitude of World Polity towards Aging Gender: An Overall Analysis}

Violations of the rights of elderly women are rampant evolves from the attitude of gender discrimination and disrespectful towards the aging group. Though the old women contribute the family by rendering their services either in formal or informal way or in both capacity but usually they don't get the recognition or value for their responsibility rather they are often considered as burden on their family.

A large chunk of aging women do not have any social security to run their livelihood, to take care of their old age, to get medical treatment and to fulfill their bare necessities of life and that is why either they compelled to depend on their family or on society even completely compromising with their dignity. As per the estimation of WHO, updated October 2015 around 1 in 10 older people experience abuse every month though a considerable number of old people 
never complain against their abuser either for apprehending fear or considering their past social status. So the condition of older women is really appalling one and needs immediate intervention of world polity to inform them justice.

Though the shield of legal protection has been extended to the half of the humanity in International arena, but needless to mention, not proved very effective to wipe the tears of the elderly women. So far, the international legal mechanism is concerned we will find the preamble of Universal Declaration of Human Right, 1948 (UDHR) affirms the equal right of 'Man' and 'Women' and all are entitled to enjoy a dignified life. Hence, UDHR ensures that aging groups are also entitled to enjoy a quality life. Art.25 of UDHR specifically incorporates the issues of elder generation as it mandates that they have the right to a standard of living adequate for their health and well-being.

The World Assembly on Aging, Vienna, 1982 incorporated an international plan of action on aging which focuses for carefulness towards the need of the elders and to provide them a just, human and prosperous life. Again in the year 2002 at the Second World Assembly on Aging the Madrid International Plan of Action on Aging and the Political Declaration was adopted with an intention to ameliorate the conditions of older people. The action plan was initiated to respond to the opportunities and challenges of population aging in the $21^{\text {st }}$ century and to promote the development of a society for all ages. In the year 1995 the Committee on Economic, Social and Cultural Rights adopted General Comment
No. 6, which mandates the obligations of States parties to apply the provisions of International Covenant on Economic, Social and Cultural Rights to older persons too.

Convention on the Political Rights of the Women of the United Nation held at New York in 1953 advocated for conferring equal rights to females as available to their male counterpart so that they may take part in decision making process of their respective states, avail public services and enjoy all the political rights available to man in the society. The Elimination of all Forms of Discrimination against Women, 1979 was an epoch making convention which affirms to end those cultures and tradition which creates gender discrimination and creates impediments into the way of development of the potentiality of women. This was the first world convention which recognized the reproductive rights of women.

The Second World Conference on Women held in Copenhagen in 1980, recognized women's ownership and control of property and has also ensured improvements in women's rights with respect to inheritance, child custody and of nationality. The Beijing Conference on Women, held in 1995 gave stress on reevaluation of relationship in between man and women so that women are fully empowered to act independently and as equal partner with the male in all aspects of life. The Committee on the Elimination of Discrimination against Women adopted General Recommendation No. 27 in the year 2010 to protect rights of older women too under the Convention on the Elimination of Discrimination against Women. 


\section{CONCLUSION}

Despite of incorporating various international instruments, covenants, conventions in international legal framework, the world polity failed to inform justice to the aging women. Perhaps, it is the high time to incorporate a separate universal human right instrument for aging people. Beside this the United Nation along with the International Organizations different NGO's should actively take the measures for eradication of gender discrimination and to prevent inhuman treatment inflicted on aging women. World polity should take the scheme for all round development of women which should include spread of quality education, proper health system, supply of nutritious diet and ensuring their all kind of social, economic and political rights. Granny battering, sexual abuse on fair sex, gender discrimination indicates towards a bad culture and a blot to our civilization but the dichotomy is that the society has nurtured this negative culture from time immemorial. The United nation and the different agencies should engage themselves in creating public opinion and public awareness against torturing of elders and gender biasness.

It is worthwhile to quote a letter shared by Pat Moore in her interview to Janet. This letter was read by a little child at the funeral of his grandpa where he wrote, "The best thing about my Grandpa was how he always gave me a great big hug when I got to see him. Whenever I did see him, a hug was guaranteed. When he got sick, the hugs got more gentle. And then one day, it was my job to do the hugging. Before Grandpa died, he gave me a very special gift. He gave me Venus. He told me Venus would always be there for me and that I could always see Venus because it was the brightest planet in the sky. So now when I see Venus I know that my Grandpa is telling me he loves me more than the universe." This bondage of love is the USP of humanity and humanity is the basic instinct of human being. Can't we wipe the tears of our elders and let the humanity to make its way? Hopefully we can and we are doing.

\section{BIBLIORAPHY}

Babatunde, Ekundayo B, and Babatunde E. Durowaiye. (2015). "The Conception of 'Sex' and 'Gender' as Background to Inequities Faced by Women." The Journal of Pan African Studies, 7(8): 64-79.

Catherine A. MacKinnon. (1982). "Feminism, Marxism, Method, and the State: An Agenda for Theory." Signs: Journal of Women in Culture and Society, 7(3), 515-544.

Center for Policy Research (CPR) at the Maxwell School of Syracuse University. "Quality of Life for All Ages, By Design, A conversation with Patricia Moore." Policy Brief. No. 46/2012.

Danial Latifi and another v. Union of India. (2001) 7 SCC 740

Hoffman. (2013). "Watchful Eye in Nursing Homes." The New York Times. This article appears in print on 11/19/2013, on page D1 of the NewYork edition with the headline: Watchful Eye in Nursing Homes.

Khatoon Nisa v. State of U.P. and Ors. 2002 (6) SCALE 165. 
Miriam Bernard, Judith Phillips, Linda Machin and Val Harding Davies. (2000). Women Ageing: Changing Identities, Challenging Myths. London: Routledge.

Mohd. Ahmed Khan vs Shah Bano Begum And Ors. 1985 SCC (2) 556.

Radhika Coomarswamy. (2005). "Human Security and Gender Violence." Economic and Political Weekly, 40, 44/45: 4729-4736.
Shamim Bano vs Asraf Khan. Criminal Appeal No. 820 of 2014 (Arising out of S.L.P. Criminal. No. 4377 of 2012): Available online at: www.judis.nic.in. Accessed 26 $6^{\text {th }}$ March, 2016.

Situation Analysis of the Elderly in India, June 2011, prepared by Central Statistics Office, Ministry of Statistics \& Programme Implementation, Government of India. 